\title{
SATAN IN PARADISE LOST: AN INQUIRY IN THE HEROIC NATURE OF MACHIAVELLIAN MAN
}

\section{Pathak Punit Jitendra}

\author{
Assistant Professor Faculty Of Arts, Parul University
}

This paper aims to examine and open up the idea and question of the heroic ideal in Paradise Lost using the idea of postmodernism and hsitiriography.it follows an analytical approach of Paradise Lost by John Milton. It will try and open up this question from multiples frames of reference

\section{INTRODUCTION:}

John Milton's Paradise Lost is a seminal work of art which has found a place in majority of the literary canons of the world. It is a text which leaves a mark on the reader's aesthetics as well as religico-moral aspirations and ideological presuppositions. Milton's work of art is a 12 volume exposition on "justifying the ways of god to men". It is the story of how Adam and Eve fall from the Garden of Eden and how Christ becomes the savior of mankind. It is also a metaphorical commentary on the socio-political and cultural life of England during the Elizabethan Era.

It is said and contested that Satan is the true hero of Milton's Paradise and he allowed it to develop far more than his theological pre-suppositions would have allowed. In the words of Banisalmah people of the seventeenth century were truly inspired by the writing of Milton was a Puritan poet to seek greater liberty from Religion and Roman Catholic Church. The struggle Satan against God represents this struggle of Man vs. the established structures of power and hegemony. This view further developed especially during the Romantic Age where there was a struggle against all forms of authority and which expounded on the idea of individual freedom and liberty. This view was expressed most strongly by William Blake who said that Milton depicted Satan as a character having certain qualities worthy of admiration. It was reinforced by P.B Shelly who says in Defense o Poetry "Nothing can exceed the energy and magnificence of Satan as expressed in Paradise Lost. It is a mistake to assume that he was the personification of the evil. Milton's devil has a moral far superior to god.

However the most balanced and eloquent view of the romantic ideal has been given by William Hazlitt. According to him Satan is the most balanced character and heroic subject ever chosen for an epic poem. He describes that in this poem Satan has been endowed with certain characteristics which are worthy of being a hero.

\section{DISCUSSION:}

The physical description and the dimensions of Satan as marked by Milton show him to be the hero of Paradise Lost. He is described as the one who fought against the Leviathan. He swam the huge oceans and he has a mighty stature so that when he rises the flames of hell on either side of him are thrown backwards out to billows. When this description is combined with the fact that Satan was one of the first archangels to be created who endeavored to be equal to the Almighty and who waged a war with god for the throne of universe. These two facets combined portray him as the hero of the text during a cursory reading. For this he was hurled in the depths of hell.

However a more deeper and detailed reading of the text reveals that Satan is not the manifestation of evil or the principle of malignity but rather he is the symbol of power, pride, self-ego and freewill. His love for power and absolute self-identity is such that even after being cast from heaven he does not admit defeat. He rather retreats in order to organize his creates a new empire of hell with his own palace in Pandemonium.

In all of the 12 books wherever Satan is introduced he is shown with appropriate images of grandeur and loft images of him walking and flying. He is shown to be gigantic, portentous, uneasy and disturbed. The only deformity in his form is not physical one but one of defeat an d loss of self-will. A careful reading of the text shows that Milton was far too magnanimous and took liberty sin the creation of the character of Satan. Is may not be too far to say that considering the nature of the subject of the poem Milton espoused to make him the protagonist of the narrative. Thus the Romantic idea about Satan and Milton in brief is that God is shown to be somewhat of an ambiguous and indecisive while Satan is shown with magnificentVitality.

According to Prince "Milton did must have put his heart and soul in the projection of Satan". In spite of his different purpose in mind with regard to the thematic of the poem. A similar kind of parallel dichotomy is to be found in Virgil's epic poem the Aeneid. In this poem too the central hero seems to be overshadowed by the character who was not intended to be sympathized with. Virgil's most central character of the poem is Dido who is humane and tragic and realistic; whereas Aeneas and Jupiter are like Milton's Adam and God who are pale, self-righteous and ambiguous. Thus for any conscious reader there seems to be a central dichotomy in the poems. Both Dido and Satan are far too grand and attractive for their role of villians. It seems safe to conclude that both Virgil and Milton started off with the idea of expounding certain principles in their narratives and ended up getting carried away by subjective desires and emotions. Many times artists have given us the idea that they produced effects opposite to what they originally intended. However canonical writers like Virgil and Milton were very vocal about the purposes of their narratives. Thus it seems to be unlikely that they would deliberately set out to show such moral and religious contradictions in their most seminal world.

The readers of Paradise lost who tend to glorify Satan seem to compare Milton's portrayal of god to the King Charles-I against whom it was glorious for citizens to rebel. As per Prince's view it is wild notion because "Milton conceived of God as the supreme symbol of love, mercy, justice, reason and order". The simple fact of matter is that any modern reader with modernist Sensibilities tend to move away from old world social, political, moral, ethical and cosmic ideas. These kinds of readers tend to sympathize with the characters who

\begin{tabular}{|c|c|c|}
\hline Submitted : $21^{\text {th }}$ August,2019 & Accepted : 13 & Publication : $15^{\text {th }}$ November, 2019 \\
\hline www.worldwidejournals.com & & \\
\hline
\end{tabular}


rebel in the narratives and challenge the established structures of power and hegemony. For them the sinner to be glorified while the authority to be ridiculed which is a Marxist essentialist notion. The reason for such a line of thought seems to be the move away from religion and morality due to realism, naturalism and post-modern strands of convention breaking.

The most common mistake seems to begin with the opening lines of Satan of his first speech where is surveying his followers for the first time after being cast from heaven. Murray claims that this speech should arouse horror and repulsion because it is nothing other than his egoistic pride and passion. The phrase "most potent victor in his rage.....

Nothing can make Satan repent or change". These lines embody the spirit of Puritanism. Satan seems to be seeing a conflict between as the conqueror of the world, superior force and the one who is cast from heaven. HE and by extension Milton cannot see it as conflict of good and evil. Thus the ambiguity about the central tendency of Satan as a protagonist. The critics and readers who claim to understand and realize Milton's principles can make out how far Satan is from understating true Liberty. Thus they claim that the true tyrant of the text is not God for them but Satan.

Milton's Satan and Shakespeare's Macbeth are brave, strong, generous, loyal, and self-sacrificing. In both of the narratives they are the representatives of human traits while God and nobility the representatives of goodness are centers of power and hegemony. In both the poems the poets though capable of creating a great villain but they are constrained by their traditional belief in Providence and the ultimate triumph of good over evil. So Satan and Macbeth arouse our sympathies while the idea of God and Malcolm don't. In a critical essay Anderson states that in order to allow readers to uphold or reject the divine law Milton includes elements in the poem which are opposite to the ideal of God. These elements add to the already mythical nature of Satan.

It has been the general trend of epic poems to select one character of the plethora of them in a narrative and make him or her hero of the tale. This is a basic epic convention. It has certain advantages to the narratives. It renders unity to the subject matter where there is only one hero and other characters are in the periphery. In the word of Fuller "it tends to interest us more in which enterprise which is carried on. And it gives the poet an opportunity of exerting his talent for adorning and displaying one character with peculiar splendor."

The question is asked again and again that who the hero of Paradise Lost is then. The Devil, it has always been answered by the critics again and again. But they mistake the author's intention by preceding upon a presupposition that in the end of the poem the hero should be triumphant. Whereas Milton followed a different plan and has given a tragic conclusion to a poem otherwise epic in its form.

The character of Satan has always intrigued and aroused debate in the minds of readers of Paradise Lost. Some have claimed him as the secret hero of the text but it seems to be a a misleading conception. An adversary of God has to be grand in stature and it was a huge success that Milton succeeded in creating Satan to that scale. The misinterpretation seems to stem from the fact that the modern reader seems to romanticize the rebel and their rebellion for liberty. In understanding Satan's fight against the odds one should not forget his treachery or against whom it was directed. It manifests in his desire to destroy humans a species which have not harmed him. His speeches through the twelve books seem to be bombastic and impressive but when examined they seem to be hollow and full of self-righteousness. Milton seems to have exposed all those false romantic notions of heroism as egotistical magnificence, the idea that heroic energy in a bad cause is admirable.
Dunbar states Blake made the following observation regarding Paradise Lost, " The reason Milton wrote in fetters when he wrote of angels and at liberty when of devil's and Hell is because he was a true poet and of the devil's party without knowing it." For Blake Satan is a symbol of desire, energy, and the creative force which enables man to live fully. God represents old, life-denying reason, and passivity which represent the shadow of desire. Thus the conventional ideas of heaven and god seem pale unconvincing when compared to the lofty descriptions of Hell and Satan. Satan has been described here with a wealth of imagination which makes him the hero.

The reason for so much of preoccupation with Satan is twofold. One is Milton's own fascination with the idea of devil and evil as represented in the Elizabethan era and second is the postmodern idea of affinity with the darker psyche of man rather than good. Some critics claim that Milton wanted show how evil consumed our first parents Adam and Eve. Evil can be interesting, can inspire us, and has its own perverse beauty. Milton himself condemned evil but he could yet show it at work in the temptations of Satan to Adam and Eve and it found a beautiful representation in the symbol of Pandemonium.

In Books-I and II of Paradise Lost, Satan is depicted as heroic, however it seems to be a false heroism based on false beliefs and unworthy aims and aspirations. It was Shaw-cross who represents this idea. Satan seems to be definitely perverse but his desire for revenge give shim energy and it makes him interesting and heroic. HE has all the attributes of an epic hero. At the beginning of the poem he is placed in a dramatic situation which has an emotive effect on us. And it was this deep love for emotion and personal liberty which caused Romantics like Blake and Shelly to be attracted to the character of Satan and the idea of him as a Romantic Hero. However Milton is not a romantic poet and his treatment of Satan shows the weakness of this position. On surface Satan looks heroic but he exposes the willful fancies of Satan.

Satan is a noveau character as portrayed by Milton in epic poetry. In medieval and renaissance literature the idea and Image of devil is usually monstrous one. Tasso for example shows Satan with blood shot eyes and blood dripping jaws. Such an image of devil inspires the idea of fear in man. However Milton's Satan is devilish but at the same time embodies all the human characteristics. Thus Milton humanizes his Satan and as per Daichess it is realistic and heroic-like. Satan is shown to be proud but beneath it lies the idea of a sense of despair and alienation from home. This idea of alienation overcomes him till at last all that it remains for him is revenge. In the words of Tillyard Satan's words "Myself am Hell, Nor am I out of it" in the poem suggest his heroic nature.

This outward heroic stature however diminishes in the latter books. In Nook Ib he has degenerated to an extent that he is not recognized by Gabriel his former archangel when he is seen tempting Eve. In Book IX he returns to Hell after tempting Adam and Eve and is immediately is turned into a serpent whose form he assumes while in paradise. These passages indicate a decline in his moral stature and thus in his heroic stature. They emphasize the reality beneath his pretense and increase our disbelief in his heroic nature. The first two books of Paradise Lost show Satan through his own eyes. Milton's belief about Satan but seems to be in conflict with Satan's speeches. In his speeches we forget the distinction between goodness and self-centered energy. Thus he makes himself as an epic hero however a careful analysis of his speeches reveals several evasions and assertions on his part unsupported by evidence.

Critics tend to follow this one dimensional analysis of Satan and refuse to pay attention to Milton's plain word about the 
character, conduct and moral situation of Satan. They prefer to concentrate on the heroic and romantic aspects of Satan thus missing Milton's portrayal of Satan as devil. For a careful reader Satan is just the enemy of God and Man in Paradise Lost. That is his role in the story. However he must be shown on an equal footing with his adversary possessing the necessary virtues and powers. The original sin of Satan is the same as that of Man's first disobedience of God, Pride. It is Satan's Pride from which he acts. This pride is in fact a reflection of Milton's own pride. Thus Milton unconsciously sympathizes with Satan and tries to portray him as the real hero of Paradise Lost. But this seems to be a faulty approach. It is Satan's pride which makes him claim equality with god. It is his sense of selfimportance which governs all his actions and makes him the evil of the narrative. It determines his actions and words at every stage. He is in fact a fallen angel, a lost soul incapable of repentance as seen in his soliloquy in Book IV,' Evil Be Thou my Good". It is in the human psyche to admire sometimes that which is perverse and evil. To post-modern reader unversed in Elizabethan theological speculations this approach seems proper. However Milton repeatedly tells us if his vanity and evil. Thus many regard him as a Byronic Hero who gets all credit for courage and leadership. But to understand Milton's Satan. We must seem him just as a humane tragic figure and not as some epic hero.

\section{CONCLUSION:-}

In conclusion we may safely allege there has been a conflict here between Milton's intention and the result. Satan is not a hero and a rebel but a tyrant. He is far from the idea of Liberty. He has heroic qualities indeed but these heroic qualities are imbibed in him by Milton to put on equal grounds as an adversary of the Almighty. This misinterpretation seems to arise from the tendency to romanticize the idea of a rebel and fighter again the established structures of power and hegemony and culture. Thus this paper does not claim to arrive at a conclusive answer as to who is the central hero of Paradise Lost. All it does is to try and open up the question of heroic character in the text and to try and arrive at new positions of inquiry.

\section{REFERENCES}

1. Anderson, J. K. (2010). The Decentralization of Morality in Paradise Lost. Rokcy Mountain Review, 198-204.

2. Banisalmah Ahmed, M. (2015). Milton's Anti-Monarchial Stances and His poetical, phonetic, rehtorical and theological crafts". Canadian Social Sciences, 30-34.

3. Gordon, T. (2005). Blake's The Marriage of Heaven and Hell: Paradise Lost. NewYork:Norton.

4. Hazlitt, W. (1818). On Shakespeare and Milton. In W. Hazlitt, Lectures on the English Poet.

5. Milton,J. (1749). Paradise Lost:A Poem in Twelve Books. Oxford:OUP.

6. Murray,P. (1967).Milton:The Modern Phase.New Jersey: Prentice Hall.

7. Shawcross,J.T.(1972). Milton:The Critical Heritage. Boston:Routledge.

8. Shelly Percy, B. (1998).A Defense of Poetry. New York: Blackwell Publishers. 